\title{
TIPE-TIPE KEPENGIKUTAN PEGAWAI DINAS KESEHATAN KABUPATEN MALUKU TENGGARA PROVINSI MALUKU
}

\author{
Oleh \\ Fransina Jeane Matmey ${ }^{1}$, \\ Sadu Wasistiono ${ }^{2}$, Rossy Lambelanova ${ }^{3}$ \\ 1) Pemerintah Daerah Kabupaten Maluku Barat Daya \\ Program Magister Terapan Studi Pemerintahan Daerah Institut Pemerintahan Dalam Negeri \\ janethomas977@gmail.com \\ 2,3) Institut Pemerintahan Dalam Negeri
}

\begin{abstract}
THE TYPES OF FOLLOWERSHIP AT THE SOUTHEAST MALUKU DISTRICT HEALTH OFFICE IN MALUKU PROVINCE

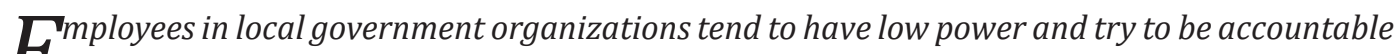
$\boldsymbol{L}_{\text {for their duties according to the rules and expectations of the leadership for the achievement }}$ of organizational goals. For example, employees at the Southeast Maluku District Health Office, who work without realizing that they have the power as followers who can have a significant role in influencing a leader's decisions, while leaders do not realize that officials have different types and characters.

The purpose of this research is to analyze and find out how the types of followership in the Southeast Maluku District Health Office, influencing factors, and followership models. The research design was qualitative with descriptive research type.

The results showed that employees at the Southeast Maluku District Health Office had different types of followers. The followership types are Isolatses, bystanders, participants, and activists, which are influenced by self-concept in the form of positive and negative perceptions of the leader and environmental conditions, and the motivation of the employees themselves. When employees have a self-concept with positive perceptions and high motivation, the employees is included in the type followers of activists, on the other hand, if self-concept with negative perceptions and lack of personel motivation, the employee is a type of isolates. Self-concept and motivation are influenced by external factors such as the leadership style of the Head of the Office, office infrastructure, and the quality of resources in the Southeast Maluku District Health Office.
\end{abstract}

Keywords: followership, leadership, dynamic governance.

\section{AbSTRAK}

$\mathrm{P}$ egawai pada organisasi pemerintah daerah cenderung memiliki kekuasaan yang rendah dan berusaha mempertanggungjawabkan tugas-tugasnya sesuai dengan aturan dan harapan pimpinan untuk pencapaian tujuan organisasi. seperti halnya para pegawai pada Dinas Kesehatan Kabupaten Maluku Tenggara, yang bekerja tanpa menyadari mereka punya 
kekuatan sebagai pengikut yang dapat memiliki peran cukup besar dalam memengaruhi keputusan pemimpin, sedangkan pemimpin tidak menyadari bahwa pegawai memiliki tipe dan karakter yang berbeda-beda.

Tujuan penelitian ini adalah untuk menganalisis dan mengetahui bagaimana tipetipe kepengikutan pegawai pada Dinas Kesehatan Kabupaten Maluku Tenggara, faktor yang memengaruhi, serta model kepengikutan pegawai. Desain penelitian adalah kualitatif dengan tipe penelitian deskriptif.

Hasil penelitian menunjukkan bahwa pegawai pada Dinas Kesehatan Kabupaten Maluku Tenggara memiliki perbedaan tipe pengikut, berupa tipe Isolates, bystanders, participants, dan activists, yang dipengaruhi oleh konsep diri berupa persepsi positif dan negatif terhadap pemimpin maupun kondisi lingkungan, dan motivasi pegawai itu sendiri. Ketika pegawai memiliki konsep diri dengan persepsi positif dan motivasi tinggi, maka pegawai tersebut termasuk dalam tipe pengikut activists, sebaliknya, jika konsep diri dengan persepsi negatif dan kurangnya motivasi pribadi, maka pegawai tersebut termasuk tipe isolates. Konsep diri dan motivasi ini dipengaruhi oleh faktor eksternal berupa gaya kepemimpinan Kepala Dinas, sarana prasarana kantor, dan kualitas sumber daya di Dinas Kesehatan Kabupaten Maluku Tenggara.

Kata kunci: kepengikutan, kepemimpinan, pemerintahan dinamis.

\section{PENDAHULUAN}

$\mathrm{M}$ unculnya hubungan yang egaliter dalam organisasi dimulai pada konsep organisasi generasi ketiga (horizontal organization) oleh Ostroff (1999), menampilkan hubungan yang melibatkan kepengikutan sebagai unsur yang ikut menentukan keberhasilan organisasi (Wasistiono, 2019: 6) organization, leadership, industry, society, mengarah pada manajemen organisasi dua inti di mana pemimpin dan bawahannya saling bekerja sama sebagai inti dalam organisasi. Namun pada kenyataannya, organisasi pemerintahan di Indonesia belum benar-benar terlepas dari Model Organisasi Generasi Kedua (Structural Organization) walaupun perkembangan organisasi secara global telah mencapai Organisasi Pemerintahan Generasi Kelima (Quantum Organization).

Perubahan dari waktu ke waktu membawa organisasi pemerintah agar lebih fleksibel, mengharapkan adanya kerja sama secara aktif antara pemimpin dan anggota organisasi dalam perencanaan, penetapan keputusan hingga pencapaian tujuan organisasi. Pemimpin tidak lagi hanya menuntut pegawainya untuk selalu mematuhi semua perintah, tetapi juga ikut mempertimbangkan pendapat pegawai untuk menyelesaikan masalah secara bersama-sama, bawahan bukan hanya dinilai sebagai bawahan karena faktor hierarkial, tetapi sebagai sesama pegawai yang bekerja sama untuk mencapai tujuan demi terwujudnya konsep kepemimpinan yang egaliter hingga konsep kepemimpinan kontemporer dengan dua inti manajemen.

Kelley (2008) dalam The Art of Followership mendefinisikan pegawai pada level bawah sebagai pengikut (follower) bukan sebagai bawahan (subordinate) karena menurutnya bawahan memiliki kekuatan dan kemampuan tersendiri dan dapat diandalkan ketika pemimpin tidak berada di tempat. Lebih lanjut, Kellerman (2008: 15) menyatakan bahwa pengikut adalah orang-orang yang dapat memilih dan memutuskan untuk mengikuti atau tidak mengikuti pemimpinnya. Sejalan dengan pendapat Kellerman tersebut, Busari, Khan, Abdullah, \& Mughal (2020) menulis:

To understand the importance of followership it has been analyzed as a moderat- 
ing variable in the relationship between transformational leadership style and factors of employees' reactions. Design/ methodology/approach A mixed methods study design was applied to investigate the factors underlying the phenomenon of transformational leadership and organizational change. A quantitative research design was followed by qualitative research questions to get more in-depth insights into the used relationships. The primary purpose of the qualitative study design was to support and strengthened the results of the main quantitative research design. Findings The results of the study showed that transformational leadership style was positively related to all three factors of employees' reactions (frequency of change, trust in management and employees' participation.

Juga berpendapat bahwa selain kepemimpinan, kepengikutan dijadikan salah satu variabel penting untuk lebih dipahami ketika terjadi perubahan-perubahan tertentu dari organisasi itu sendiri. Dengan demikian dapat dikatakan bahwa pegawai pada level bawah dewasa ini merupakan orang-orang yang aktif dan dapat berperan secara mandiri melalui ide dan inovasi masing-masing tanpa harus bergantung sepenuhnya pada pemimpin mereka. Mereka seharusnya tidak membatasi diri karena batas-batas hierarki dan kekuasaan pemimpin yang mendominasi dalam organisasi yang mengakibatkan mereka sulit berkembang. Mereka harusnya dapat dengan bebas memilih untuk mendukung atau tidak mendukung pemimpinnya ketika terjadi penyelewengan, atau hal-hal yang tidak sesuai dengan prinsipnya. Pemimpin perlu lebih jauh memahami konsep kepengikutan pada masa yang sekarang, karena menurut Grant, Willsie, \& Gupta (2020) pada kenyataannya pemimpin hanya memberi sedikit perhatian terhadap kepengikutan, padahal seharusnya pemimpin perlu memahami konsep kepengikutan, agar dapat menjadi lebih terbuka dalam membangun komunikasi terkait dengan tingkah laku, keahlian, dan keteladanan dari para pengikutnya.

Pengikut dalam organisasi pemerintahan masih sulit menerapkan hal-hal yang telah digambarkan di atas, dan masih berputar pada konsep kepemimpinan generasi kedua. Hal ini sesuai dengan pendapat Wasistiono (2017: 187-188) bahwa "kepemimpinan pemerintahan masih berada pada generasi kedua yang menyebabkan pemimpin masih bertindak sendiri dan mengakali sistem agar dapat melakukan menyalahgunakan kewenangan yang berujung pada korupsi". Hal tersebut menunjukkan bahwa kepemimpinan dalam organisasi pemerintahan sulit menerapkan konsep pemerintahan egaliter. Para pemimpin masih dengan wajar dan tanpa sadar mengabaikan posisi bawahan ketika mereka dihadapkan pada penyelewengan selama bekerja.

Kenyataan yangumumnya ditemui dalam organisasi pemerintah memperlihatkan bahwa bawahan hanya akan tetap menjadi orang-orang yang fungsinya hanya menjalankan perintah atasan apa pun itu karenaselalumemosisikan dirisebagaibagian yang tidak mempunyai kekuasaan dan hal tersebut seakan menjadi pola hidup pegawai dalam organisasi pemerintahan. Kondisi ini dianggap sebagai sesuatu yang lumrah, padahal Mayo dan Follet menyarankan para manajer untuk memperhatikan kebutuhan emosional pegawai dan memandang pegawai sebagai kombinasi yang kompleks, antara sikap, keyakinan, dan kebutuhan (Kreitner, \& Kinicki, 2014: 121). Karena bukan tidak mungkin, pegawai dapat stress dan tertekan ketika salah satu kebutuhannya berupa kebutuhan emosional ini tidak terpenuhi, dan dapat memengaruhi perilaku pegawai ketika menanggapi perintah, melaksanakan dan mempertanggungjawabkan kepada atasan dalam rangka mewujudkan pencapaian kinerja yang baik. 
Dinas Kesehatan Kabupaten Maluku Tenggara merupakan salah satu organisasi pemerintah yang mengutamakan pengoptimalan pencapaian kinerja yang efektif dan efisien. Kepala Dinas Kesehatan dengan tipe pemimpin yang tegas dan bekerja cepat, sangat menginginkan pegawai dengan tipe serupa demi terwujudnya capaian dan tujuan yang telah ditetapkan bersama. Namun, tidak semua pegawai dapat menyesuaikan dengan standar kecepatan Kepala Dinas, memiliki motivasi yang sama, atau kemampuan dan kompetensi yang sama pula. Bahkan dapat memiliki tanggapan yang berbeda dengan cara kepemimpinan Kepala Dinas walaupun tidak berani diungkapkan, dan hal tersebut dianggap normal. Hal ini sesuai dengan paradigma yang dikemukakan oleh Stech (2008: 44) bahwa pemimpin natural yang efektif fokus terhadap tujuan spesifik dan bekerja keras untuk itu, dan "pengikut yang normal" adalah mereka yang menjunjung tinggi loyalitas dan penyesuaian terhadap gaya kepemimpinan natural tersebut.

Penyesuaian terhadap gaya kepemimpinan kerap kali mengesampingkan kebutuhan pegawai yang sebenarnya selain kebutuhan akan peningkatan kompetensi dan kemampuan, dan pemimpin dapat mulai belajar pula untuk memahami tipe pengikut dalam menghadapi perubahan-perubahan organisasi karena menurut Manning \& Robertson (2016) keahlian yang dibutuhkan pemimpin dapat muncul dan dibangun dari peran pengikut, demi terwujudnya kepemimpinan yang lebih baik pada masa yang akan datang, agar pemimpin tidak sering mengharapkan pegawai untuk mengikuti aturan main pemimpin demi menciptakan keserasian dalam organisasi, seperti yang dikemukakan oleh Maccoby (2008: 215) bahwa pegawai membutuhkan pemimpin dengan konsep kepemimpinan yang baru, di mana tidak hanya menjadi pengikut melainkan menginginkan pemimpin yang dapat berkolaborasi dan menunjukkan makna dalam mencapai tujuan.
Tanggapan pegawai Dinas Kesehatan Kabupaten Maluku Tenggara terhadap gaya kepemimpinan Kepala Dinasnya menghasilkan pola pikir dan tindakan yang berbeda-beda. Menurut Lord (2008: 257) kondisi tersebut dapat terjadi karena adanya pembentukan struktur mental berupa sensemaking dan self-regulation karena melibatkan faktor kognitif dan afektif dari masing-masing pengikut. Maka dapat dikatakan bahwa pengikut dapat menunjukkan karakter dan perilaku yang berbeda dalam pelaksanaan tugas seharihari, di mana terdapat pegawai yang memiliki kesadaran rendah terhadap masalah yang dihadapi organisasi ditunjukkan dengan disiplin yang rendah, pegawai yang terus melaksanakan tugas tanpa banyak komentar karena merasa citra kinerja yang baik adalah kepastian dan kewajiban seorang pegawai, pegawai dengan inisiatif belajar lebih banyak meskipun sarana dan prasarana belum memungkinkan, hingga adanya pengaruh hubungan keluarga dan kepentingan subjektif kepada pemimpin dalam pengambilan keputusan.

Berdasarkan hal tersebut di atas, dapat disimpulkan bahwa pegawai sebagai pengikut pada organisasi, khususnya organisasi pemerintah seperti Dinas Kesehatan Kabupaten Maluku Tenggara memiliki tipe-tipe kepengikutan yang berbeda-beda, dipengaruhi oleh faktorfaktor eksternal dan internal, serta dapat membentuk model kepengikutan tertentu sesuai dengan kenyataan di lapangan. Hal ini sejalan dengan Kellerman (2008) yang membedakan tipe kepengikutan berdasarkan level keterikatan pengikut terhadap pemimpin maupun organisasi. Tipe-tipe tersebut adalah isolates, bystanders, participants, activists, dan diehards.

\section{METODE PENELITIAN}

Metode penelitian yang digunakan adalah metode penelitian kualitatif, dengan 
pendekatan deskriptif. Teknik analisis yang yang diperoleh melalui observasi, dokumentasi, dan wawancara, adalah reduksi data, penyajian data, dan penarikan simpulan, sesuai dengan model oleh Miles dan Huberman.

\section{HASIL DAN PEMBAHASAN}

Tipe-tipe kepengikutan diidentifikasi dan dianalisis dari kebutuhan, keinginan, atau ekspektasi para pegawai para pegawai ketika berusaha memberi kepuasan kepada Kepala Dinas atas apa yang mereka kerjakan, juga sebaliknya kepuasan yang mereka dapatkan sebagai pegawai dari pemimpin maupun organisasi. Hasil penelitian menunjukkan bahwa tidak semua pegawai cocok dan memiliki kepuasan pribadi ketika bekerja memenuhi ekspektasi pimpinan atau kepuasan terhadap cara memimpin dari Beliau. Sebanyak 8\% dari pegawai menyatakan ketidakpuasan, namun tidak pernah menyatakan secara langsung. Hal ini sesuai dengan pernyataan Kellerman bahwa ketidakpuasan atau perlawanan terhadap kekuasaan dapat dilakukan secara tersembunyi dan tidak terlihat (resistance to power can be covert, hidden from view (Kellerman, 2008: 65)).

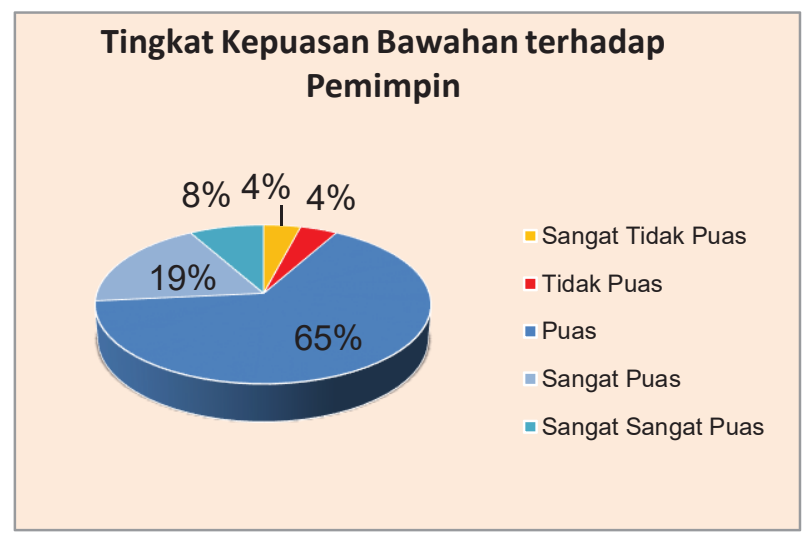

Beranjak dari tingkat kepuasan pegawai Dinas Kesehatan tersebut, dapat dianalisis dan ditentukan tipe-tipe kepengikutan pegawai berdasarkan wawancara, dokumentasi dan obeservasi di lapangan. Berdasarkan analisis data dan observasi yang dilakukan, dapat diidentifikasi bahwa pegawai pada Dinas Kesehatan memiliki empat tipe kepengikutan, yaitu isolates, bystanders, participants, dan activists. Dengan perhitungan persentase:

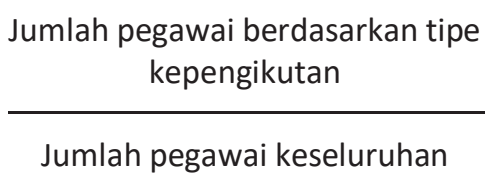

masing-masing persentase sebagai berikut.

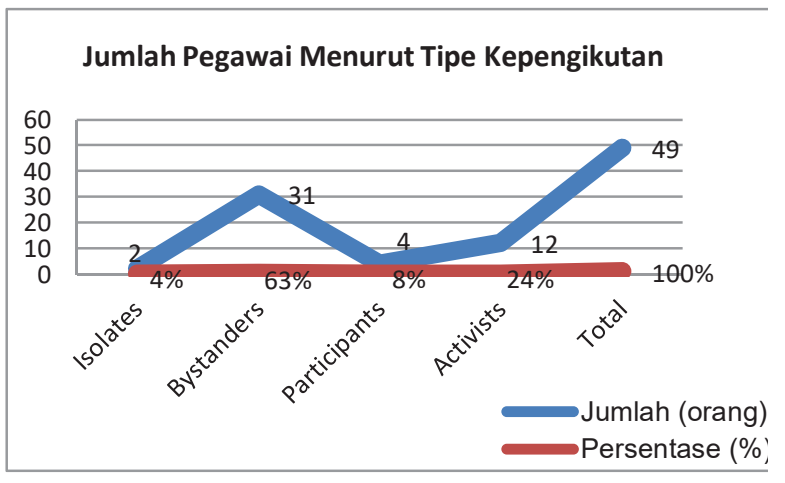

Berikut adalah penjelasan mengenai tipe-tipe kepengikutan pegawai pada Dinas Kesehatan Kabupaten Maluku Tenggara berdasarkan data yang ditemukan di lapangan.

\section{The Bystanders (Para Pengamat)}

Tipe kepengikutan pegawai dengan jumlah terbanyak adalah tipe bystanders. Ketidakpuasan pegawai mengakibatkan dukungan yang rendah pula terhadap pemimpin, membuat para pegawai tersebut memilih untuk tidak berpihak atau mendukung keputusan pemimpin. Dari 4 pegawai yang memberikan pendapat sangat tidak puas dan tidak puas, hanya 1 pegawai yang berani menyampaikannya kepada Kepala Dinas, yaitu pegawai dengan Jabatan Kepala Bidang. Tiga pegawai lainnya memilih untuk diam saja dan tidak melakukan apa pun walaupun peka dengan cara memimpin Kepala Dinas. 
Pegawai dengan tipe bystanders tidak berusaha untuk menentang atau menyampaikan pendapat tentang kondisi bidangnya dan memilih untuk tetap mengikuti aturan kerja dari pemimpin walaupun hal tersebut menimbulkan masalah dalam penyelesaian tugas-tugas bidangnya. Pegawai tersebut akhirnya menyerahkan semua keputusan kepada pimpinan karena berpandangan bahwa sebagai bawahan sudah semestinya ikut apa kata pimpinan. Pandangan ini mengandung kebiasaan-kebiasaan pegawai pada umumnya dalam lingkup Pemerintahan Daerah. Kondisi tersebut menurut Howell \& Mendez (2008: 28) menggambarkan bahwa pegawai tersebut memiliki tipe the yes people yang mengikuti keinginan pemimpin karena hitung-hitungan dalam motivasi, yaitu karena menginginkan imbalan atau ingin memenuhi kebutuhan atas keamanan dan perlindungan terhadap ancaman di lingkungan sekitar. Oleh karena itu, mereka menyerah pada keputusan pemimpin dan "menyadari posisi mereka" (their motivation is often calculative, to secure their desired rewards from the leader or to satisfy their need for safety or security in a threatening environment. They yield to the leader's judgement and "know their place".

Situasi ini menunjukkan bahwa meskipun memiliki jabatan sebagai Kepala Bidang, persepsi bawahan sebagai orang yang kurang berkuasa masih sangat melekat, seperti menyatakan mengikuti pemimpin namun tidak melakukan apa pun ketika menemui ketidakcocokan dengan keputusan pimpinan. Keputusan untuk tidak berpendapat menurut beberapa pegawai dilakukan karena kemungkinan pendapat mereka diterima sangat kecil, dan akan berdampak buruk terhadap hubungan mereka dengan pimpinan karena perbedaan pendapat.

Dari para pegawai yang menyatakan puas sebanyak $65 \%$ dapat diketahui bahwa 44\%-nya adalah pegawai pada level paling bawah, yaitu staf, dan 35\% dari staf tersebut adalah pegawai yang mencerminkan tipe pengikut bystanders karena merasa tidak pernah berinteraksi langsung dengan Kepala Dinas selain bertatap muka melalui apel. Mereka merasa tidak memiliki ikatan yang kuat antara pemimpin dan bawahan karena level jabatan yang terlampau jauh sehingga menampilkan pula dukungan yang rendah dari pemimpin pada level paling atas, padahal Myung, Bruce, \& Jaehee (2016) dalam penelitian mereka, pegawai akan menjadi pengikut secara aktif yang merasakan kepuasan kerja ketika merasakan dukungan supervisor yang tinggi. Selain itu, menurut mereka keaktifan pengikut juga bergantung pada tipe-tipe dari faktorfaktor situasi organisasi yang berbeda-beda, perilaku, dan keterlibatan pemimpinnya. Namun, sehubungan dengan hal tersebut, sebagian besar dari para staf menurut atasan langsung, yaitu Kepala Seksi dan Kepala Bidang adalah pegawai-pegawai yang dapat berpartisipasi aktif dan dapat diandalkan.

\section{The Activists (Para Aktivis)}

Tipe kepengikutan selanjutnya, adalah tipe kepengikutan activists dengan persentase $24 \%$, dan semua pegawai tersebut adalah pegawai pada level menengah dengan jabatan eselon III dan IV. Pegawai dengan tipe ini menunjukkan pemahaman yang lebih baik dibandingkan tipe lainnya, mengenai pola pemikiran Kepala Dinas dan dapat bertindak sesuai. Bahkan sebelum diberi perintah, seperti menyiapkan data dan dokumen yang dibutuhkan terkait dengan suatu pekerjaan sebelum Kepala Dinas memberi arahan, sehingga ketika ditanya segala sesuatu telah tersedia, sehingga Pemimpin lebih banyak mendelegasikan tugas pada pegawaipegawai dengan tipe activists karena mampu menyelesaikan tugas dengan cepat.

Hal ini menunjukkan bahwa pegawai pada level menengahlah yang paling sering berinteraksi dengan Kepala Dinas tidak merasa keberatan ketika ingin menyampaikan suatu pendapat sebagai 
hasil dari interaksi yang intens, sebagaimana organisasi pemerintahan pada umumnya yang mencerminkan hubungan administratif dari atas hingga ke bawah sesuai dengan jabatan dan tugas-tugas yang melekat setiap tingkatannya, sehingga para pejabat pada level menengah, khususnya pejabat eselon IV, tidak begitu sulit mengomunikasikan halhal terkait dengan penyelesaian pekerjaan.

Berbeda dengan pegawai yang berada pada level paling bawah, yang merasa kurang diperhatikan karena jarang berinteraksi secara langsung dengan Kepala Dinas. Oleh sebab itu, penyampaian perbedaan pendapat tersebut hanya berani dilakukan oleh para pegawai eselon III dan IV yang memiliki hubungan kedekatan dengan beliau lebih daripada pegawai yang lain, karena sejauh pengamatan dan wawancara, belum ada staf yang berani memberi masukan secara langsung. Hal ini menurut Surur (2019) mencerminkan hubungan administratifbirokratif sesuai dengan otoritas legal oleh Weber, yang menyatakan bahwa "Hierarki yang paling atas memiliki otoritas tertinggi untuk mengambil kebijakan. Memiliki otoritas untuk memberi instruksi pada hierarki bawahannya, tanpa harus mendiskusikan pada hierarki bawahnya apalagi pegawai dalam birokrasi. Hierarki yang paling bawah harus selalu siap menjalankan perintah dari atasannya lebihlebih para staf pegawai".

\section{The Participants (Para Peserta) dan The Isolates (Orang-Orang Asing)}

Tipe kepengikutan participants dan isolates memiliki persentase yang sedikit, yaitu 8\% dan 4\%. Meskipun demikian persentase tersebut tidak boleh diabaikan. Tipe participants menyatakan dukungan kepada Kepala Dinas, dan mengakui Kepala Dinas sebagai pemimpin yang menginspirasi untuk lebih baik dari hari ke hari. Selain daripada itu, terdapat pula pegawai yang tidak hanya menunjukkan keberpihakan terhadap pemimpin, tetapi juga menunjukkan sikap berani mengungkapkan hal-hal kecil dan tidak sesuai dengan tugasnya kepada pemimpin. Pada Dinas Kesehatan Kabupaten Maluku Tenggara terdapat pegawai yang berani menyatakan pendapat tidak setuju atau tidak sejalan dengan pemahaman mereka secara pribadi atas pekerjaan yang biasanya mereka lakukan ketika Kepala Dinas tidak memiliki pemahaman yang sama tentang cara menyelesaikan tugas tersebut. Namun, tindakan tersebut tidak jarang berujung konflik di antara pemimpin dan pegawai, padahal kritik dan konflik dalam organisasi dapat membentuk penyesuaian gaya kepemimpinan yang lebih transformasional karena mempertimbangkan pendapat dari pengikut, seperti yang dinyatakan oleh Nawaz et al (2019) bahwa pengaruh kepengikutan yang dapat membentuk kepemimpinan transformasional, dan dimensi kepengikutan secara positif memengaruhi terbentuknya kepemimpinan transformasional, hingga terbentuk hubungan kepercayaan antara keduanya secara langsung. Hal ini berarti kepengikutan merupakan dasar terbentuknya kepercayaan dan kepemimpinan transformasional bukan gaya kepemimpinan yang tradisional. Pendapat Nawaz et al (2019) juga didukung oleh penelitian yang dilakukan Li, Zhao, Müller, \& Shao (2020) yang mengidentifikasi hubungan antara kepemimpinan manajer dan pengikut mereka, dan menempatkan kepengikutan sebagai unsur penting dalam memahami dan memprediksi perilaku serta menyeleksi para manajer berdasarkan tipe pengikut itu sendiri.

Berdasarkan Observasi yang dilakukan dalam jangka waktu satu bulan, ditemukan bahwa terdapat dua orang pegawai aktif yang memiliki tipe pengikut Isolate. Kedua pegawai tersebut tidak pernah melakukan resistensi yang berarti dan selalu mengikuti apel pagi, namun ketika mendekati jamjam makan siang hingga lewat jam makan siang, mereka jarang sekali terlihat di 
ruangan. Bahkan salah satunya beberapa kali pulang ke rumah setelah selesai apel pagi. Interaksi antara pegawai tersebut dengan pegawai satu sub-bagian dengannya jarang dilakukan, karena pegawai tersebut jarang berada di ruangan sehingga tugas yang diberikan kepadanya terkadang lalai dikerjakan, salah satunya ketika diberi tugas sebagai pramutamu. Tugas tersebut tidak dilaksanakan dengan maksimal karena yang bersangkutan sering meninggalkan tempat pada saat jam kantor, akibatnya tamu tidak lagi mengantre dan menunggu di ruang tamu, namun langsung masuk ke dalam ruangan dan tidak menjaga jarak. Tindakan tersebut menunjukkan sikap tidak bertanggung jawab atas tugas yang diberikan dan secara tidak langsung menganggap sepele jabatannya sebagai pramutamu.

Pegawai dengan kondisi tersebut di atas menunjukkan kesadaran yang sangat rendah, juga tidak memahami informasi terhadap peraturan perundang-undangan mengenai disiplin Pegawai Negeri Sipil, karena jika pegawai tersebut menyadari bahwa seorang pegawai diikat berbagai aturan, dan memahami informasi peraturan yang berlaku, maka pelanggaran disiplin harusnya tidak terjadi, karena menurut Harlie (2010) "disiplin kerja pada hakikatnya adalah menumbuhkan kesadaran bagi para pekerjanya untukmelakukan tugas yang telah dibebankan". Pegawai dengan tipe tersebut sudah lama ada di dalam Dinas Kesehatan Kabupaten Maluku Tenggara, namun upaya yang dilakukan untuk mengatasi tipe pegawai seperti ini tidak serius dan belum maksimal.

Berdasarkan data-data tersebut dapat disimpulkan bahwa pegawai-pegawai tersebut memiliki tipe kepengikutan isolates karena mereka memiliki kesadaran bekerja yang sangat rendah, motivasi menurun karena fasilitas tidak mendukung, hingga tidak memahami aturan tentang pelanggaran disiplin dan hal ini dapat memperlambat pertumbuhan organisasi juga berdampak buruk terhadap hubungan antar sesama pegawai, sesuai dengan pendapat Yang, Shi, Zhang, Song, \& Xu (2020) implicit attitude and consequences of followers' implicit followership theories in the Chinese cultural context through three studies. Study 1 explores the structure of followers' implicit followership theories. Study 2 examines the implicit attitude of followers towards followers' implicit followership theories. Study 3 verifies the impact of followers' implicit followership theories on the quality of collegial relationships. Design/methodology/approach The data for study 1 ( $n=321$ bahwa model kepengikutan yang negatif sangat memberi dampak negatif pula terhadap hubungan kolegial dalam organisasi.

\section{Faktor-Faktor yang Memengaruhi}

\section{- Faktor Internal}

Berdasarkan data yang didapatkan melalui wawancara, observasi dan dokumentasi selama melakukan penelitian pada Dinas Kesehatan Kabupaten Maluku Tenggara, penulis dapat menyimpulkan faktor internal yang memengaruhi tipe pengikut dalam organisasi. Faktor internal yang dapat diindentifikasi pada pegawai Dinas Kesehatan adalah konsep diri dan motivasi dari pengikut. Konsep diri adalah faktor paling mendasar dalam menentukan perilaku mengandung kebutuhan emosional pegawai yang sangat kompleks, di mana menurut Mayo dan Follet patut dipertimbangkan oleh para manajer selama saling berinteraksi menyelesaikan tugas (Kreitner \& Kinicki, 2014).

Di dalam konsep diri terdapat tiga komponen pembentuk persepsi, keputusan mengambil tindakan, dan cara pegawai bertahan, yaitu (1) sensemaking; kepekaan pegawai menanggapi proses dan kejadian sosial di mana kepemimpinan termasuk di dalamnya; (2) self-regulation; mengarahkan pegawai dalam menentukan motivasi dan tindakan sosial (Lord, R, 2008: 255); dan 
(3) Self-protective; tindakan melindungi diri sendiri terhadap ancaman, risiko, dan konsekuensi yang dapat muncul ketika menentukan pilihan (Chaleff, 2008: 386).

Pegawai yang menunjukkan sensemaking dan self-regulation yang positif dalam menghadapi Kepala Dinas yang dapat dilihat dari cara pegawai tersebut menentukan dasar pemikiran bahwa upaya melihat keteladanan pemimpin juga harus disertai kebijaksanaan dan kesadaran akan kekurangan yang dimiliki sebagai bawahan, sehingga dari pengenalan akan kekurangan diri sendiri Ia dapat berusaha menutupi kekurangan tersebut dengan memperkaya wawasan dan kemampuan agar dapat berpikir selangkah lebih maju dalam memahami maksud pimpinan.

Pegawai dengan persepsi negatif terhadap gaya kepemimpinan Kepala Dinas akan berpikir sebaliknya dari pegawai di atas. Ia menempatkan karakter Kepala Dinas sebagai ancaman bagi dirinya sehingga memilih melindungi diri dengan tidak melakukan apa pun.

Faktor Internal berupa motivasi melibatkan upaya setiap orang dalam mencari jalan keluar untuk memuaskan kebutuhan mereka ketika merasakan adanya kesenjangan kebutuhan atau munculnya kebutuhan-kebutuhan tertentu yang harus dipenuhi baik untuk diri sendiri maupun untuk pekerjaannya, melalui pilihan perilaku yang dianggap sesuai, kemudian mengevaluasi diri dengan tujuan untuk menentukan kebutuhan pada masa depan. Hal ini sejalan dengan pendapat Dweck (2020: 236) yang menyatakan bahwa "manusia lahir dengan temperamen tertentu tetapi bagaimana mereka diperlakukan, menentukan cara temperamen itu mengekspresikan diri".

Pegawai pada Dinas Kesehatan membutuhkan motivasi berupa pemenuhan kebutuhan atas penghargaan terhadap penyelesaian tugas-tugas yang mereka kerjakan. Mereka mengakui bahwa dapat bekerja lebih giat lagi apabila Kepala Dinas memberikan perhatian-perhatian berupa pemberian pujian atau mengevaluasi pekerjaannya mengenai apa yang dapat dilakukan atau apa yang harus dihindari, sebagai upaya menghadapi masa kerja yang dinamis dan cepat berubah.

Pernyataan-pernyataan di atas menggambarkan adanya stimulan berupa kebutuhan akan kepedulian dari orang lain yang dapat memberikan rangsangan pada motivasi pegawai untuk menyelesaikan tugas. Ketika bentuk konsep diri atau prinsip dan nilai-nilai yang mereka percaya berupa kebutuhan akan kepedulian tidak sejalan dengan ekspektasi orang lain serta kondisi lingkungan sekitar, maka hal ini akan mendorong mereka untuk menemukan tindakan dan cara yang tepat untuk menghadapi hal tersebut, yang tentu saja akan membawa penilaian tertentu bagi orang lain, dan mereka akan melakukan hal yang sama pula, seperti halnya pemimpin menentukan cara yang tepat untuk memperlakukan bawahannya sesuai dengan tipe-tipe masing-masing bawahan.

\section{- Faktor Eksternal}

Faktor eksternal yang dapat disimpulkan dalam penelitian ini, yaitu gaya kepemimpinan dan kondisi lingkungan organisasi berupa sumber daya manusia, dan sarana prasarana. Faktor yang berasal dari luar diri pegawai ini memberikan stimulan yang cukup besar bagi pegawai dalam memutuskan untuk memilih tindakan yang tepat dalam menentukan apakah pegawai harus peduli kepada pemimpin dan organisasi atau tidak. Hasil wawancara dan observasi menunjukkan bahwa terdapat beberapa hal yang berasal dari luar diri pegawai dan dapat memengaruhi tipe kepengikutan mereka di antaranya yaitu

1. Kebutuhan akan dukungan, bimbingan dan arahan dari pimpinan, di mana pemimpin dapat berkomunikasi secara 
terbuka agar pegawai dapat mengerti apa dan bagaimana tugas harus diselesaikan;

2. Pemenuhan akan fasilitas kantor, berupa komputer, AC, koneksi internet yang baik, dan ruangan yang kondusif.

3. Kondisi lingkungan yang membatasi ruang gerak karena harus menaati protokol kesehatan, membuat kinerja tidak maksimal;

4. Pekerjaan yang tumpang tindih, karena beban kerja tidak sebanding dengan jumlah pegawai;

5. Kerja sama yang baik antara sesama rekan;

6. Kebutuhan akan penghargaan dan pujian dari pimpinan

\section{Model Kepengikutan Pegawai pada Dinas Kesehatan Kabupaten Maluku Tenggara}

Berdasarkan penelitian yang telah dilakukan tentang tipe-tipe kepengikutan pegawai pada Dinas Kesehatan, dapat diidentifikasi dan dianalisis bahwa pegawai memiliki empat tipe kepengikutan, yaitu Isolates, Bystanders, Participants, dan Activists. Tipe kepengikutan tersebut dipengaruhi oleh gaya kepemimpinan pemimpin dan faktor organisasional yang memberi stimulasi kepada pegawai dalam membentuk persepsi dan tindakan yang menurut mereka merupakan respons yang tepat.

Kepala Dinas Kesehatan menurut sebagian besar pegawai adalah pemimpin yang kurang membangun komunikasi dengan bawahan khususnya bawahan pada level paling bawah. Bagi mereka Kepala Dinas lebih mengutamakan kapabilitas pegawai di mana pegawai harus mencapai kinerja yang maksimal, namun mereka jarang diberi dukungan secara moril, yaitu dengan memberikan bantuan kepada pegawai berupa dukungan batin, bukan berupa uang ataupun barang. Berbeda dengan pandangan sebagian besar pegawai dengan jabatan eselon III dan IV, mereka memiliki pendapat bahwa Kepala Dinas merupakan sosok yang menginspirasi mereka untuk bekerja lebih baik.

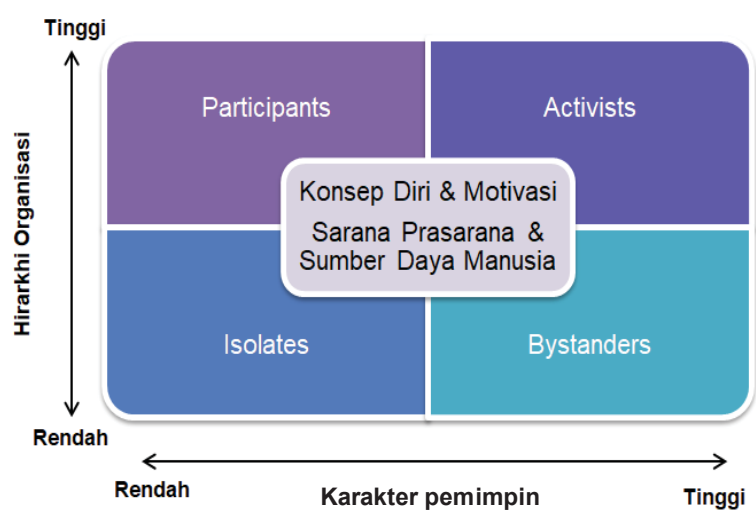

Pegawai pada Dinas Kesehatan Kabupaten Maluku Tenggara yang memiliki Tipe kepengikutan isolate disebabkan oleh rendahnya posisi pegawai dalam hierarki organisasidan rendahnyaperhatian pemimpin terhadap pegawai-pegawai tersebut, sehingga mereka menunjukkan tindakan yang sama, yaitu dengan tidak memberikan perhatian dan kepedulian terhadap lingkungan maupun pemimpin karena tidak terbiasa untuk diberikan perhatian.

Pegawai dengan tipe bystander didominasi oleh para staf pada level bawah, memiliki kepekaan yang sangat tinggi terhadap gaya kepemimpinan Kepala Dinas dan lingkungan organisasi. Mereka memiliki berbagai keluhan dan kebutuhan tertentu sebagai pegawai namun tidak ingin menyampaikan selain karena posisinya rendah dalam organisasi karena mereka merasa adanya gap berupa tingkatan jabatan dalam organisasi yang membatasi mereka untuk menyampaikan keluhan dan kebutuhan secara langsung. Selain itu, karakter kepemimpinan Kepala Dinas yang temperamen dan mudah marah membuat pegawai menyimpan semua keluhan dengan tujuan ingin melindungi diri dari konflik dalam organisasi. 
Tipe participant umumnya adalah pegawai yang menilai bahwa Kepala Dinas adalah sosok yang inspiratif. Mereka memiliki jabatan dalam organisasi dan berani mengungkapkan perbedaan pendapat secara langsung kepada Kepala Dinas, namun terdapat pegawai yang tidak lagi benarbenar mendukung keputusan Kepala Dinas karena pendapatnya tidak diterima dan tidak lagi dilibatkan dalam kegiatan-kegiatan pada organisasi.

Pegawai dengan tipe activists adalah para pegawai pada level menengah, yaitu pegawai yangmemilikijabatan eselonIII danIV.Mereka sangat puas dengan gaya kepemimpinan Kepala Dinas dan menunjukkan tanggapan dan tindakan serupa, yaitu dengan bekerja sesuai dengan harapan. Bahkan berupaya melebihi ekspektasi pimpinan, yaitu dengan peka terhadap hal-hal kecil sekalipun dan menemukan ide untuk memudahkan pekerjaan pada masa yang akan datang. Mereka tidak sungkan menyatakan pendapat karena jenjang jabatan yang dimiliki sangat dekat dengan jabatan Kepala Dinas.

\section{SIMPULAN}

Berdasarkan hasil wawancara, observasi serta dokumentasi dan pengolahan data untuk menganalisis dan mengetahui tipe-tipe pegawai dalam kepemimpinan perempuan pada Dinas Kesehatan Kabupaten Maluku Tenggara yang dilakukan selama penelitian, maka penulis dapat menyimpulkan beberapa hal sebagai berikut.

Pertama, tipe kepengikutan pegawai Dinas Kesehatan Kabupaten Maluku Tenggara terdiri dari empat tipe, yaitu Isolates, Bystanders, Participants, dan Activists.

a. Isolates memiliki karakter tidak bertanggung jawab sebagai pelayan masyarakat juga terhadap tugas yang diberikan atasan dan merupakan pegawai dengan pelanggaran disiplin; b. Bystanders adalah pegawai yang peka terhadap lingkungan organisasi dan pemimpin namun acuh dan bersikap abai terhadap permasalahan yang muncul dalam organisasi karena ingin melindungi diri dan menghindari konflik;

c. Participants terdiri dari para pegawai yang ingin berkontribusi dan memiliki kepuasan terhadap kepemimpinan Kepala Dinas, dan juga terdiri dari pegawai-pegawai yang tidak ingin mendukung dan menyesuaikan diri dengan kepemimpinan Kepada Dinas karena merasa tidak didengar; dan

d. Activists adalah para pegawai yang benar-benar menjadikan Kepala Dinas sebagai teladan, memiliki persepsi positif dan selalu berusaha memahami pola pikir Kepala Dinas.

Tipe kepengikutan pegawai pada Dinas Kesehatan Kabupaten Maluku Tenggara sangat besar dipengaruhi oleh gaya kepemimpinan Kepala Dinas, karena mereka mempunyai pola pikir "menyesuaikan pemimpin adalah hal yang wajib dilakukan bawahan", dan membuat sebagian besar dari mereka ragu dan tidak berani menyampaikan pendapat. Hal ini dikarenakan pengaruh hierarki organisasi yang masih sangat kuat.

Kedua, Faktor internal yang memengaruhi tipe kepengikutan adalah Konsep diri; yang menjadi dasar untuk membentuk persepsi, keputusan untuk bertindak, dan cara pegawai bertahan, dan motivasi setiap pegawai yang menentukan bagaimana pegawai mengekspresikan diri terhadap kesenjangan kebutuhan dalam organisasi. Sedangkan Faktor eksternal yang memengaruhi adalah ekspektasi pemimpin, gaya kepemimpinan, dan faktor-faktor dalam organisasi, seperti jumlah sumber daya manusia dan sarana prasarana.

Ketiga, model kepengikutan pegawai pada Dinas Kesehatan Kabupaten Maluku Tenggara adalah sebagai berikut. 


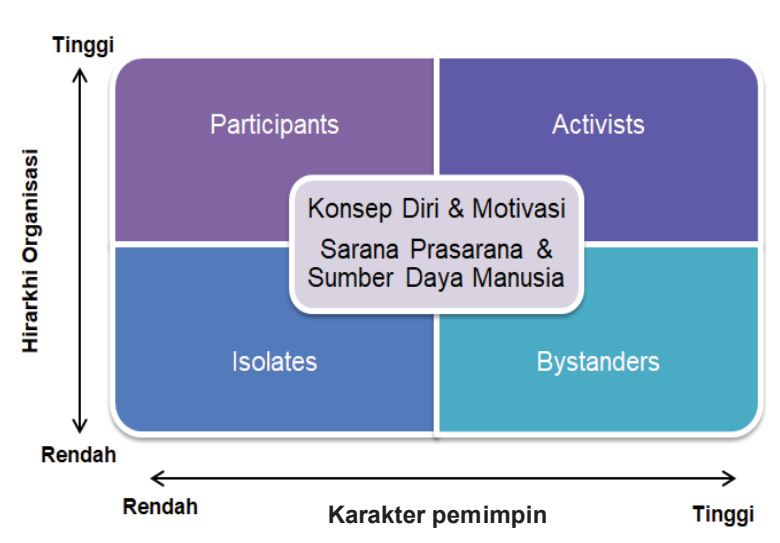

SARAN

Untuk mewujudkan Kepengikutan yang baik, adapun saran yang dapat penulis berikan adalah sebagai berikut.

Pertama, pemimpin harus memahami bahwa pegawai memiliki tipe-tipe yang berbeda dengan pola pikir dan tindakan yang berbeda pula sebagai hasil dari stimulasi berupa gaya kepemimpinan pemimpin dan kondisi lingkungan kerja. Hal ini dapat dilakukan melalui penyediaan ruang-ruang diskusi dan evaluasi dalam lingkup organisasi, agar pemimpin dapat mengetahui tipe-tipe pengikut sekaligus kebutuhan-kebutuhan mereka dengan baik.

Kedua, perlu adanya dukungan moril dan pemberian motivasi baik berupa pujian atau penghargaan kepada pegawai, juga pemberian pengertian yang baik kepada pegawai agar tidak muncul ketidakpuasan terhadap gaya kepemimpinan. Pegawai dengan tipe Isolate dan Bystanders tidak sama dengan pegawai dengan tipe Participants dan Activists, di mana mereka lebih banyak membutuhkan perhatian, kesempatan untuk mengemukakan pendapat, dan penghargaan atas pencapaian yang diraih oleh mereka, sehingga dapat terbentuk pola pikir positif dan motivasi yang tinggi dalam bekerja karena merasa diayomi sebagai bawahan. dan pegawai harus dapat membuka diri untuk membangun budaya keterbukaan dan membesarkan hati terhadap keragaman dan perbedaan. Selain itu, perlu adanya peningkatan sarana-prasarana penunjang penyelesaian pekerjaan seperti penyediaan unit-unit komputer, meja dan kursi, dan wifi dengan konektivitas yang baik, agar tidak menghambat pegawai dalam menyelesaikan tugas-tugas. Juga, perlu adanya penambahan jumlah pegawai agar pegawai yang lainnya tidak kewalahan menyelesaikan semua tugas sekaligus. Pemimpin perlu menyediakan sarana atau ruang untuk mendengar keluhan pegawai terhadap proses keberlangsungan penyelesaian tugas;

Ketiga, pemimpin perlu menyesuaikan gaya kepemimpinan dengan tipe pengikut untuk mewujudkan model kepengikutan pegawai yang ideal.

\section{DAFTAR RUJUKAN}

Busari, A. H, Khan, S. N, Abdullah, S. M, \& Mughal, Y. H. (2020). Transformational leadership style, followership, and factors of employees' reactions towards organizational change. Journal of Asia Business Studies, 14(2), 181-209. https:// doi.org/10.1108/JABS-03-2018-0083

Dweck, C. S. (2020). Self Theories (Wawasan Psikologi Terbaru tentang Motivasi, Kepribadian, dan Pengembangan Diri) (D. Pranasari, ed.). Tangerang Selatan: BACA.

Grant, S, Willsie, S, \& Gupta, G. (2020). Thriving in the future: intentional followership development. Industrial and Commercial Training, ahead-of-p(ahead-of-print). https://doi.org/10.1108/ICT-02-20200021

Harlie, M. (2010). Pengaruh Disiplin Kerja, Motivasi dan Pengembangan Karier terhadap Kinerja Pegawai Negeri Sipil Pada Pemerintah Kabupaten Tabalong di Tanjung Kalimantan Selatan. Jurnal Manajemen dan Akuntansi, 11, 117-124.

Howell, J. P, \& Mendez, M. J. (2008). Three Perspective on Followership. In R. E. Riggio, I. Chaleff, \& J. Lipman-Blumen (Eds.), The art of followership: How great followers create great leaders and 
organizations. (p. 25). United States of America: A Wiley Imprint.

Kellerman, B. (2008). Followers (How Followers are Creating Change and Changing Leaders. United States of America: Harvard Business School.

Kelley, R. E. (2008). Rethinking followership. In The Warren Bennis Signature Series. The art of followership: How great followers create great leaders and organizations. (pp. 5-15). Hoboken, NJ, US: Jossey-Bass/ Wiley.

Kreitner, R. Kinicki, A. (2014). Perilaku Organisasi. Jakarta: Salemba Empat.

Li, H, Zhao, Z, Müller, R, \& Shao, J. (2020). Exploring the relationship between leadership and followership of Chinese project managers. International Journal of Managing Projects in Business, 13(3), 616-647. https://doi.org/10.1108/ IJMPB-02-2019-0042

Lord, R, G. (2008). Followers' Cognitive and Affective Structure and Processes. In R. E. Riggio, I. Chaleff, \& L. Blumen, J. (Eds.), The art of followership: How great followers create great leaders and organizations. (p. 255). United States of America: A Wiley Imprint.

Maccoby, M. (2008). What Kind of Leader Do People Want t Follow? In R. E. Riggio, I. Chaleff, \& J. Lipman-Blumen (Eds.), The art of followership: How great followers create great leaders and organizations. (pp. 209-217). United States of America: A Wiley Imprint.

Manning, T, \& Robertson, B. (2016). A three factor model of followership: part 1- introduction to followership, leadership and the three factor model of leadership. Industrial and Commercial Training, 48(6), 277-283. https://doi. org/10.1108/ICT-01-2016-0003

Myung, J, Bruce, M, \& Jaehee, P. (2016). Followership and job satisfaction in the public sector: The moderating role of perceived supervisor support and performance-oriented culture. International Journal of Public Sector
Management, 29(3), 218-237. https:// doi.org/10.1108/IJPSM-05-2015-0101

Nawaz, K. S, Mariam, A. S, Halim, B. A, Muhammad, M, \& Ullah, K. I. (2019). Reversing the lens: The role of followership dimensions in shaping transformational leadership behaviour; mediating role of trust in leadership. Leadership \& Organization Development Journal, 41(1), 1-18. https://doi.org/10.1108/LODJ-032019-0100

Stech, E. L. (2008). A New LeadershipFollowership Paradigm. In R. E. Riggio, I. Chaleff, \& J. Lipman-Blumen (Eds.), The art of followership: How great followers create great leaders and organizations. (p. 41). United States of America: A Wiley Imprint.

Surur, M. (2019). Birokrasi Weberian: "Proportional Approach." Madani Jurnal Politik dan Sosial Kemasyarakatan, 11(2), 86-104. Retrieved from https://ejurnal.unisda.ac.id/index.php/MADANI/ article/view/1601

Wasistiono, S. (2017). Perkembangan Ilmu Pemerintahan (Dari Klasik Sampai Ke Kontemporer). Sumedang: IPDN Press.

Wasistiono, S. (2019). ASPEK PEMERINTAHAN dan PERUBAHAN KOMPREHENSIF ERA DIGITAL. Jurnal Ilmu Pemerintahan Widya Praja, 45(1), 1-16. https://doi. org/10.33701/jipwp.v45i1.350

Yang, Y, Shi, W, Zhang, B, Song, Y, \& Xu, D. (2020). Implicit followership theories from the perspective of followers. Leadership \& Organization Development Journal, 41(4), 581-596. https://doi.org/10.1108/ LODJ-05-2019-0225 
Visioner ! Vol. $13 \backslash$ No. 3\Desember 2021 